\title{
Partial replacement of fish and soyabean meal protein in mirror carp (Cyprinus carpio) diets by protein in hazelnut meal
}

\author{
H.M. Buyukcapar ${ }^{1}$ and A. Kamalak ${ }^{2}$ \\ ${ }^{1}$ Department of Fisheries, Faculty of Agriculture, University of Kahramanmaras Sutcu Imam, 46100 Kahramanmaras, \\ Turkey \\ ${ }^{2}$ Department of Animal Sciences, Faculty of Agriculture, University of Kahramanmaras Sutcu Imam, 46100 \\ Kahramanmaras, Turkey
}

\begin{abstract}
An 80-day feeding trial was conducted as two experiments to evaluate the effects of replacement of fish meal (FM) and soyabean meal (SBM) protein with hazelnut meal (HM) protein in the diets of mirror carp (Cyprinus carpio) fingerlings. Growth parameters and body composition were measured in fingerlings cultured under laboratory conditions in a recirculation system aquarium at $26 \pm 0.3^{\circ} \mathrm{C}$. In Experiment I four isonitrogenous, isoenergetic diets were formulated by replacing 0, 25, 35 and 45\% of protein from FM by HM. Fingerlings receiving the diets in which 0, 25 and 35\% of the FM protein were replaced, had similar body weights, specific growth ratios (SGR), protein efficiency ratios (PER) and feed conversion ratios (FCR). In Experiment II four isonitrogenous, isoenergetic diets were formulated by replacing 0, 20, 40 and $60 \%$ of protein in SBM with HM. Fingerlings receiving the diets where 0, 20 and 40\% of the SBM protein were replaced, had similar body weights, SGR, PER and FCR. However, fingerlings consuming the highest dietary inclusion level of HM (60\% replacement) had significantly lower responses for all the above parameters than fingerlings receiving the other diets. The fat content of fingerlings fed diet $\mathrm{FM}_{3}$ where $45 \%$ of FM protein was replaced by HM protein, was significantly lower than those on the other diets. It was concluded that HM could replace up to $35 \%$ of the protein in FM and $40 \%$ of protein supplied by SBM in fingerling carp diets without adverse effects on growth, FCR, PER, FI, BWG and body composition.
\end{abstract}

Keywords: Fish, hazelnut meal, fish meal, soyabean meal, Cyprinus carpio, aquaculture

\#Corresponding author. E-mail: hakanmurat@ksu.edu.tr

\section{Introduction}

A main objective of fish culturing is to maximize both survival and growth rates at least cost. Feed cost is the largest production cost for commercial aquaculture. Moreover, fish meal (FM) prices have risen in real terms in the past three decades and are likely to increase further with continued growth in demand. Fish meal production is also rather heavily localized in some regions of the world resulting in becoming more expensive and difficult to obtain in many countries practicing aquaculture (Tacon \& Jackson, 1985; Hossain et al., 2001; Adebyo et al., 2004). Considerable attention has been paid to the replacement of FM with plant protein sources such as soyabean meal (SBM) (Oliva-Teles et al., 1994; Refstie et al., 1998), Mauna seed meal (Siddhuraju \& Becker, 2001), winged bean (Fabgenro, 1999) and various legume seed (Gouveia \& Davies, 1998; Hossain et al., 2001; Buyukcapar \& Kamalak, 2006). Research on the inclusion of plant-based ingredients in practical diets for salmonids and omnivorous fish such as channel catfish, tilapia and carp has shown that partial replacement of FM is feasible (Davies et al., 1990; Webster et al., 1992).

This becomes imperative as availability of unconventional protein sources used in fish diet formulation in developing countries is a prerequisite for increased fish production (Adebyo et al., 2004). Particularly, soyabean products have been used to replace a significant portion of FM protein in fish diets with nutritional, environmental and economic benefits (Lim \& Akiyama, 1992; Rumsey et al., 1993; Kaushik et al., 1995; Naylor et al., 2000). However, the rapid expansion of the livestock industry in many parts of the world is absorbing almost all of the feedstuffs produced, thus increasing the cost of conventional crops including legume feedstuffs used in aquaculture feeds (Siddhuraju \& Becker, 2002).

The hazelnut is cultivated for its nuts in commercial orchards in Turkey, Europe, China and Australia. Hazelnut production in Turkey was about 480.000 tons (in shell) in 2003 (SIS, 2004). Hazelnuts are extensively used in confectionery to value chocolate for chocolate truffles and products such as nutella. 
Hazelnut meal (HM) resulting from the solvent extraction of hazelnut oil is readily available (Yalcin et al., 2005). Although HM was evaluated for rainbow trout by Bilge (2006), so far there have been no published studies on the use of $\mathrm{HM}$ as a protein resource in mirror carp (Cyprinus carpio L) diets. The objective of the present study was to evaluate the effects of replacing the protein supplied by FM or soyabean meal with HM on the growth parameters and body composition of mirror carp fingerlings cultured under laboratory conditions.

\section{Materials and Methods}

Mirror Carp (C. carpio) fingerlings derived from brood stock held at the State Hydraulic Works (Adana, Turkey) where artificial insemination was used in the reproduction of the fish were transferred to the Department of Fisheries, Faculty of Agriculture and University of Kahramanmaras Sutcu, Imam and maintained in a 250-L fibreglass tank until they reached a body weight of approximately $10 \mathrm{~g}$. In the preparatory phase the carp were raised at $26 \pm 1{ }^{\circ} \mathrm{C}$ to the starting body mass of about $10.68 \pm 0.16 \mathrm{~g}$. They were kept in high quality water on a diet containing approximately $350 \mathrm{~g}$ protein $/ \mathrm{kg}, 80 \mathrm{~g} \mathrm{lipid} / \mathrm{kg}, 7 \mathrm{~g}$ ash/kg and with an energy content of $13.54 \mathrm{MJ} \mathrm{ME} / \mathrm{kg}$ dry matter. At the start of the experiment this diet was replaced by the experimental diets. Five days prior to the start of the experiment, carp of comparable body weights were selected from a large population, weighed and placed in the respiration aquaria. Fish fry were randomly allocated at a stocking rate of 10 fish per aquaria. Each diet was tested in two replicate aquariums. All fish were fed by hand twice a day at a fixed feeding rate of $3 \%$ body weight per day for 80 days. At the end of the trial, three fish per aquarium were sampled to determine whole body composition.

A recirculation system contained a set of aquaria, each with a capacity of $c a .80 \mathrm{~L}$ and maintained at $26 \pm 0.3^{\circ} \mathrm{C}$. A photoperiod was set at $12 \mathrm{~h}$ light and $12 \mathrm{~h}$ dark. Water quality was monitored throughout the study (temperature and dissolved oxygen daily, $\mathrm{pH}$ and nitrogenous compounds every week). Mean recorded values ( \pm s.e.) were: temperature $26 \pm 0.1^{\circ} \mathrm{C}, \mathrm{pH} 7.03 \pm 0.2$, dissolved oxygen $7.7 \pm 0.22 \mathrm{mg} / \mathrm{L}$, total ammonium $0.345 \pm 0.02 \mathrm{mg} / \mathrm{L}$ and nitrite $0.035 \pm 0.003 \mathrm{mg} / \mathrm{L}$. Water quality was maintained using a biologic filter and electronic heater. Water was recirculated through the filter at a rate of $5 \mathrm{~L} / \mathrm{min}$. Additional aeration was provided by an inflator. During acclimatization the carp were fed the same ration at twice maintenance. The chemical compositions of FM (IFN 5-02-025), SBM (IFN 5-04-604) and HM (TS 323/T1:2004) are given in Table 1.

Table 1 Proximate compositions and estimated gross energy content of fish meal (FM), soyabean meal (SBM) and hazelnut meal (HM) used in the experimental diets

\begin{tabular}{|c|c|c|c|}
\hline Constituents (g/kg) & FM & SBM & $\mathrm{HM}$ \\
\hline Dry matter & 900.6 & 890.0 & 880.0 \\
\hline Crude protein & 701.6 & 470.0 & 390.0 \\
\hline Crude fat & 113.3 & 10.0 & 20.0 \\
\hline Crude ash & 135.0 & 60.0 & 70.0 \\
\hline Crude fibre & 5.0 & 60.0 & 80.0 \\
\hline Gross energy (MJ/kg) ${ }^{1}$ & 21.3 & 17.5 & 16.9 \\
\hline
\end{tabular}

${ }^{1}$ Gross energy was estimated using the following coefficients: $23.6 \mathrm{KJ} / \mathrm{g}$ for crude protein; $39.5 \mathrm{KJ} / \mathrm{g}$ for crude fat and $17.2 \mathrm{KJ} / \mathrm{g}$ for carbohydrates (NRC, 1993)

In Experiment I four isonitrogenous, isoenergetic diets were formulated to evaluate the nutritive value of HM for carp fingerlings. The control diet contained $403 \mathrm{~g} / \mathrm{kg}$ FM and $150 \mathrm{~g} / \mathrm{kg}$ SBM as main protein sources. Hazelnut meal was tested at three inclusion levels (25, 35 and 45\% replacement of FM protein) by reducing FM levels. The composition of the experimental diets is given in Table 2. Ingredients were mixed, formed into a moist pellet about $2 \mathrm{~mm}$ in diameter and then dried in a forced-air oven at $45^{\circ} \mathrm{C}$. 
In Experiment II four isonitrogenous, isoenergetic diets were also formulated to evaluate the nutritional value of HM replacing the protein in SBM in the diets of carp fingerlings. Details of ingredients and proximate composition of the diets used for the second trial are given in Table 3. The method of preparation of the diets was similar to that adopted in Experiment I. The control diet contained $250 \mathrm{~g} \mathrm{FM} / \mathrm{kg}$ and $390 \mathrm{~g} \mathrm{SBM} / \mathrm{kg}$ as main protein sources. Hazelnut meal was tested at three inclusion levels (20, 40 and $60 \%$ replacement of SBM protein) by reducing SBM levels (Table 3).

Table 2 Ingredients, chemical composition and estimated gross energy content of the diets used in Experiment I where fish meal protein was partially replaced by protein in hazelnut meal (as fed)

\begin{tabular}{|c|c|c|c|c|}
\hline \multirow[b]{2}{*}{ Replacement of FM protein (\%) } & \multicolumn{4}{|c|}{ Experimental diets } \\
\hline & 0 & 25 & 35 & 45 \\
\hline & Control & $\mathrm{FM}_{1}$ & $\mathrm{FM}_{2}$ & $\mathrm{FM}_{3}$ \\
\hline \multicolumn{5}{|l|}{ Ingredients (g/kg) } \\
\hline Fish meal & 400 & 306 & 260 & 220 \\
\hline Soyabean meal & 150 & 150 & 150 & 150 \\
\hline Hazelnut meal & - & 180 & 280 & 380 \\
\hline Maize flour & 350 & 240 & 170 & 95 \\
\hline Sunflower oil & 89 & 110 & 125 & 138 \\
\hline Dicalcium phosphate & 1 & 2 & 2 & 3 \\
\hline Vit.-Min. ${ }^{1}$ & 5 & 5 & 5 & 5 \\
\hline Limestone & 1 & 1.5 & 1.5 & 2 \\
\hline Kavilamisin ${ }^{2}$ & 1 & 1 & 1 & 1 \\
\hline Salt & 1 & 1.5 & 1.5 & 2 \\
\hline Methionine & 1 & 1.5 & 2 & 2.5 \\
\hline Lysine & 1 & 1.5 & 2 & 2.5 \\
\hline Total & 1000 & 1000 & 1000 & 1000 \\
\hline \multicolumn{5}{|l|}{ Composition (g/kg) } \\
\hline Dry matter & 891.2 & 887.0 & 885.3 & 890.0 \\
\hline Crude protein & 371.0 & 370.2 & 369.6 & 373.2 \\
\hline Crude fat & 165.5 & 170.0 & 168.8 & 173.3 \\
\hline Crude ash & 72.0 & 75.0 & 73.9 & 73.6 \\
\hline Crude fibre & 28.3 & 29.0 & 31.3 & 37.4 \\
\hline Gross energy $(\mathrm{MJ} / \mathrm{kg})^{3}$ & 20.3 & 20.4 & 20.6 & 20.7 \\
\hline
\end{tabular}

${ }^{1}$ Per 5 kg vitamin-mineral premix: 20.000.000 IU vitamin A; 2.00 .000 IU vitamin D3; 200.000 mg vitamin E; 12.000 $\mathrm{mg}$ vitamin $\mathrm{K}_{3} ; 20.000 \mathrm{mg}$ vitamin $\mathrm{B}_{1} ; 30.000 \mathrm{mg}$ vitamin $\mathrm{B}_{2} ; 200.000 \mathrm{mg}$ niacin; $50.000 \mathrm{mg}$ Ca-panthothenate; 20.000 $\mathrm{mg}$ vitamin $\mathrm{B}_{6} ; 50 \mathrm{mg}$ vitamin $\mathrm{B}_{12} ; 500 \mathrm{mg}$ D-biotin; $1.200 \mathrm{mg}$ folic acid; $200.000 \mathrm{mg}$ vit $\mathrm{C}$ and $300.000 \mathrm{mg}$ inositol; 1.200 .000 mg cholin chloride; 40.000 mg Mn; 30.000 mg Zn; 800 mg Co; 1.000 mg I; 150 mg Se; 40.000 mg Mg

${ }^{2}$ Kavilamisin ${ }^{\circledR}$ containing Avilamicin $10.000 \mathrm{mg} / \mathrm{kg}$

${ }^{3}$ Gross energy was estimated using the following coefficients: $23.6 \mathrm{KJ} / \mathrm{g}$ for crude protein; $39.5 \mathrm{KJ} / \mathrm{g}$ for crude fat and $17.2 \mathrm{KJ} / \mathrm{g}$ for carbohydrates (NRC, 1993) 
Growth performances were evaluated as body weight gain (BWG), feed conversion ratio (FCR) and specific growth rate (SGR):

Body weight gain $(\mathrm{BWG})(\mathrm{g})=\mathrm{Fi} W(\mathrm{~g})-$ in W $(\mathrm{g})$

Feed conversion ratio $(\mathrm{FCR})=($ dry feed consumed $(\mathrm{g}) /$ live body weight $(\mathrm{g}))$

Specific growth rate $(\mathrm{SGR})=100 \times(\ln (\mathrm{Fi} \mathrm{W})-\ln ($ in W $))$

Feed intake $(\mathrm{g})$ per fish $=$ (Total feed consumption $(\mathrm{g})$ per aquaria) $/$ (number of fish per aquaria).

Table 3 Ingredients, chemical composition and estimated gross energy content of the diets used in Experiment II where soyabean meal (SBM) protein was partially replaced by protein in hazelnut meal (as fed)

\begin{tabular}{|c|c|c|c|c|}
\hline \multirow[b]{2}{*}{ Replacement of SBM protein (\%) } & \multicolumn{4}{|c|}{ Experimental diets } \\
\hline & 0 & 20 & 40 & 60 \\
\hline & Control & $\mathrm{SBM}_{1}$ & $\mathrm{SBM}_{2}$ & $\mathrm{SBM}_{3}$ \\
\hline \multicolumn{5}{|l|}{ Ingredients (g/kg) } \\
\hline Fish meal & 250 & 250 & 250 & 250 \\
\hline Soyabean meal & 390 & 310 & 230 & 150 \\
\hline Hazelnut meal & - & 100 & 200 & 300 \\
\hline Maize flour & 233.5 & 210 & 178.5 & 152.5 \\
\hline Sunflower oil & 115 & 118 & 129 & 135 \\
\hline Dicalcium phosphate & 1 & 1 & 1 & 1 \\
\hline Vit.-Min. ${ }^{1}$ & 5 & 5 & 5 & 5 \\
\hline Limestone & 1 & 1 & 1 & 1 \\
\hline Kavilamisin $^{2}$ & 1 & 1 & 1 & 1 \\
\hline Salt & 2 & 2 & 2 & 2 \\
\hline Methionine & 1 & 1.5 & 2 & 2 \\
\hline Lysine & 0.5 & 0.5 & 0.5 & 0.5 \\
\hline Total & 1000 & 1000 & 1000 & 1000 \\
\hline \multicolumn{5}{|l|}{ Composition (g/kg) } \\
\hline Dry matter & 891.2 & 889.6 & 892.3 & 879.9 \\
\hline Crude protein & 371.0 & 372.4 & 371.1 & 370.0 \\
\hline Crude fat & 159.5 & 161.4 & 168.0 & 174.7 \\
\hline Crude ash & 65.0 & 66.1 & 68.0 & 69.7 \\
\hline Crude fibre & 37.1 & 36.5 & 38.9 & 40.4 \\
\hline Gross energy $(\mathrm{MJ} / \mathrm{kg})^{3}$ & 20.5 & 20.5 & 20.7 & 20.8 \\
\hline
\end{tabular}

${ }^{1}$ Per 5 kg vitamin-mineral premix: 20.000.000 IU vitamin A; 2.00.000 IU vitamin D3; 200.000 mg vitamin E; 12.000 mg vitamin $\mathrm{K}_{3} ; 20.000 \mathrm{mg}$ vitamin $\mathrm{B}_{1} ; 30.000$ mg vitamin $\mathrm{B}_{2} ; 200.000$ mg niacin; 50.000 mg Ca-panthothenate; 20.000 mg vitamin $\mathrm{B}_{6} ; 50 \mathrm{mg}$ vitamin $\mathrm{B}_{12} ; 500 \mathrm{mg}$ D-biotin; $1.200 \mathrm{mg}$ folic acid; $200.000 \mathrm{mg}$ vit $\mathrm{C}$ and $300.000 \mathrm{mg}$ inositol; 1.200.000 mg cholin chloride; 40.000 mg Mn; 30.000 mg Zn; 800 mg Co; 1.000 mg I; 150 mg Se; 40.000 mg Mg

${ }^{2}$ Kavilamisin ${ }^{\circledR}$ containing Avilamicin $10.000 \mathrm{mg} / \mathrm{kg}$

${ }^{3}$ Gross energy was estimated using the following coefficients: $23.6 \mathrm{KJ} / \mathrm{g}$ for crude protein; $39.5 \mathrm{KJ} / \mathrm{g}$ for crude fat and 17.2 KJ/g for carbohydrates (NRC, 1993) 
Experimental diet ingredients and fish samples were analyzed for their proximate composition according to the methods of AOAC (1990). A completely randomized design was adopted with two replicates per diets. Each replicate had 10 fish. Fish in each replicate were group fed. Fish were individually weighed at the start of the experiment ( 0 day) and at 20 day intervals (20, 40, 60 and 80 days). One-way analysis of variance (ANOVA) was carried out to determine the effect of diets on growth parameters using General Linear Model (GLM) of Statistica for Windows (1993). Significant differences between individual means were identified using the Duncan's multiple comparison test. Mean differences were considered significant at $\mathrm{P}<0.05$.

\section{Results}

Fish in all dietary groups fed actively on the experimental diets. There was no rejection of feed until the end of the experiment. The acceptability of the diets was more or less similar. No mortality or any signs of disease were observed in any of the dietary groups during the study period. The body weight of fish increased with increasing age.

At the end of Experiment I there were no differences $(\mathrm{P}>0.05)$ in the body weight between the $\mathrm{FM}_{1}$, $\mathrm{FM}_{2}$ and Control diets. However, fish fed diet $\mathrm{FM}_{3}$ showed reduced $(\mathrm{P}<0.05)$ growth performance compared with fish on the other diets (Table 4). Body weights of the fish ranged from 29.7.6 \pm 0.2 to 45.7 $\pm 0.2 \mathrm{~g}$. The feed intake (FI) and growth parameters such as BWG, FCR, SGR and PER are presented in Table 4. The FI of the fish fed on the $\mathrm{FM}_{3}$ diet was lower $(\mathrm{P}<0.05)$ than in the others. Fish fed on the Control, $\mathrm{FM}_{1}$ and $\mathrm{FM}_{2}$ diets had similar BWG values while fish fed the $\mathrm{FM}_{3}$ diet had lower $(\mathrm{P}<0.05)$ BWG values than those on the other diets. Fish fed the control, $\mathrm{FM}_{1}$ and $\mathrm{FM}_{2}$ diets had similar FCR, SGR and PER values whereas fish fed on the $\mathrm{FM}_{3}$ diet had lower $(\mathrm{P}<0.05)$ FCR, SGR and PER values than those on the other diets. Fingerlings fed the diet with $45 \%$ replacement had the lowest and poorest results.

Table 4 Growth parameters of mirror carp obtained in Experiment I where fish meal protein was partially replaced by protein in hazelnut meal $(n=20)$

\begin{tabular}{lrrrr}
\hline & \multicolumn{4}{c}{ Experimental diets } \\
\hline Replacement (\%) & \multicolumn{1}{c}{0} & 25 & \multicolumn{1}{c}{35} \\
\cline { 2 - 5 } Parameters & \multicolumn{1}{c}{ Control } & \multicolumn{1}{c}{$\mathrm{FM}_{1}$} & \multicolumn{1}{c}{$\mathrm{FM}_{2}$} & \multicolumn{1}{c}{$\mathrm{FM}_{3}$} \\
\hline In W (g) & $10.9^{\mathrm{a}} \pm 0.2$ & $10.4^{\mathrm{a}} \pm 0.1$ & $10.6^{\mathrm{a}} \pm 0.1$ & $10.9^{\mathrm{a}} \pm 0.2$ \\
Fi W (g) & $45.7^{\mathrm{a}} \pm 0.2$ & $45.5^{\mathrm{a}} \pm 0.2$ & $43.6^{\mathrm{a}} \pm 0.1$ & $29.7^{\mathrm{b}} \pm 0.2$ \\
BWG (g) & $34.8^{\mathrm{a}} \pm 0.9$ & $35.1^{\mathrm{a}} \pm 0.8$ & $33.0^{\mathrm{a}} \pm 0.9$ & $18.8^{\mathrm{b}} \pm 1.0$ \\
FCR & $1.4^{\mathrm{a}} \pm 0.1$ & $1.4^{\mathrm{a}} \pm 0.1$ & $1.5^{\mathrm{b}} \pm 0.1$ & $2.0^{\mathrm{c}} \pm 0.4$ \\
FI (g/fish) & $47.2^{\mathrm{a}} \pm 2.3$ & $46.3^{\mathrm{a}} \pm 2.2$ & $47.6^{\mathrm{a}} \pm 2.1$ & $36.1^{\mathrm{b}} \pm 2.3$ \\
SGR & $2.2^{\mathrm{a}} \pm 0.1$ & $2.3^{\mathrm{a}} \pm 0.1$ & $2.2^{\mathrm{a}} \pm 0.2$ & $1.5^{\mathrm{b}} \pm 0.1$ \\
PER & $2.1^{\mathrm{a}} \pm 0.1$ & $2.1^{\mathrm{a}} \pm 0.1$ & $2.2^{\mathrm{a}} \pm 0.1$ & $1.2^{\mathrm{b}} \pm 0.1$ \\
\hline
\end{tabular}

${ }^{\mathrm{abc}}$ Row means with common superscript do not differ $(\mathrm{P}>0.05)$

Diets $\mathrm{FM}_{1}, \mathrm{FM}_{2}, \mathrm{FM}_{3}$ contain 180, 280, $380 \mathrm{~g}$ hazelnut meal/kg, respectively

In W - initial body weight; Fi W - final body weight; FI - feed intake; BWG - body weight gain; FCR - feed conversion ratio; SGR - specific growth rate; PER - protein efficiency ratio

The effect of diets on whole body composition of mirror carp fingerlings at the end of the feeding Experiment $\mathrm{I}$ is given in Table 5. Fish fed on the Control and $\mathrm{FM}_{1}$ diets had a similar fat content. However, fish fed on diets $\mathrm{FM}_{2}$ and $\mathrm{FM}_{3}$ had a significantly lower fat content than those on the other diets.

At the end of Experiment II there were no significant $(\mathrm{P}>0.05)$ differences in the body weight between the Control, $\mathrm{SBM}_{1}$ and $\mathrm{SBM}_{2}$ treatments. However, fish fed diet $\mathrm{SBM}_{3}$ showed a reduced $(\mathrm{P}<0.05)$ 
growth performance compared with those on the other diets. The body weights of the fish ranged from 37.8 \pm 0.1 and $45.0 \pm 0.1 \mathrm{~g}$ (Table 6). The FI and growth parameters, BWG, FCR, SGR and PER, are presented in Table 6. Feed intake of fish fed the $\mathrm{SBM}_{3}$ diet was lower $(\mathrm{P}<0.05)$ than the others. Fish in the Control, $\mathrm{SBM}_{1}$ and $\mathrm{SBM}_{2}$ treatments had similar BWG values. Fish receiving the $\mathrm{SBM}_{3}$ diet had significantly lower BWG values than those on the other treatments. Fish fed the Control, $\mathrm{SBM}_{1}$ and $\mathrm{SBM}_{2}$ diets had similar FCR, SGR and PER values while those on the $\mathrm{SBM}_{3}$ diet had significantly lower FCR, SGR and PER values. Fingerlings receiving the diet $\mathrm{SBM}_{3}$ where $60 \%$ of SBM protein replaced by $\mathrm{HM}$ had the lowest and poorest performance results.

Table 5 Whole body composition (\%) (wet weight basis) of mirror carp fed test diets in Experiment I where fish meal protein was partially replaced by protein in hazelnut meal $(n=6)$

\begin{tabular}{lrrrr}
\hline Constituents (\%) & Control & \multicolumn{1}{c}{$\mathrm{FM}_{1}$} & \multicolumn{1}{c}{$\mathrm{FM}_{2}$} & \multicolumn{1}{c}{$\mathrm{FM}_{3}$} \\
\hline Dry matter & $28.1^{\mathrm{a}} \pm 0.9$ & $29.4^{\mathrm{ab}} \pm 0.7$ & $30.8^{\mathrm{b}} \pm 0.6$ & $28.1^{\mathrm{a}} \pm 0.9$ \\
Protein & $12.5^{\mathrm{a}} \pm 0.1$ & $12.7^{\mathrm{a}} \pm 0.1$ & $12.6^{\mathrm{a}} \pm 0.2$ & $12.7^{\mathrm{a}} \pm 0.2$ \\
Fat & $12.7^{\mathrm{a}} \pm 0.2$ & $13.3^{\mathrm{a}} \pm 0.4$ & $11.7^{\mathrm{b}} \pm 0.3$ & $9.5^{\mathrm{c}} \pm 0.1$ \\
Ash & $1.7^{\mathrm{a}} \pm 0.2$ & $2.3^{\mathrm{a}} \pm 0.3$ & $2.3^{\mathrm{a}} \pm 0.2$ & $2.2^{\mathrm{a}} \pm 0.1$ \\
\end{tabular}

${ }^{a b c}$ Row means with common superscript do not differ $(\mathrm{P}>0.05)$

Diets $\mathrm{FM}_{1}, \mathrm{FM}_{2}, \mathrm{FM}_{3}$ contain 180, 280, 380 g hazelnut meal $/ \mathrm{kg}$, respectively

The effect of diets on whole body composition of the mirror carp fingerlings at the end of the feeding Experiment II is given in Table 7. Fish fed on the Control and $\mathrm{SBM}_{1}$ diets had a similar fat content. However, fish receiving the diet $\mathrm{SBM}_{2}$ had a significantly lower fat content than those fed the Control diet.

Table 6 Growth parameters of mirror carp obtained in Experiment II where soyabean meal (SBM) protein was partially replaced by protein in hazelnut meal $(n=20)$

\begin{tabular}{lrccc}
\hline & \multicolumn{4}{c}{ Experimental diets } \\
\hline \multirow{2}{*}{ Replacement (\%) } & \multicolumn{1}{c}{0} & \multicolumn{1}{c}{20} & 40 & 60 \\
\cline { 2 - 5 } Parameters & Control & \multicolumn{1}{c}{$\mathrm{SBM}_{1}$} & $\mathrm{SBM}_{2}$ & $\mathrm{SBM}_{3}$ \\
\hline \multirow{2}{*}{ In W (g) } & $10.9^{\mathrm{a}} \pm 0.2$ & $10.9^{\mathrm{a}} \pm 0.1$ & $10.4^{\mathrm{a}} \pm 0.1$ & $10.6^{\mathrm{a}} \pm 0.1$ \\
Fi W (g) & $45.0^{\mathrm{a}} \pm 0.1$ & $43.1 \pm 0.1$ & $43.1^{\mathrm{a}} \pm 0.1$ & $37.8^{\mathrm{b}} \pm 0.1$ \\
BWG (g) & $34.1^{\mathrm{a}} \pm 0.9$ & $32.2^{\mathrm{a}} \pm 0.7$ & $32.6^{\mathrm{a}} \pm 0.7$ & $27.1^{\mathrm{b}} \pm 0.7$ \\
FCR & $1.4^{\mathrm{a}} \pm 0.1$ & $1.4^{\mathrm{a}} \pm 0.2$ & $1.4^{\mathrm{a}} \pm 0.1$ & $1.7^{\mathrm{b}} \pm 0.2$ \\
FI (g/fish) & $47.2^{\mathrm{a}} \pm 2.3$ & $46.3^{\mathrm{a}} \pm 2.1$ & $46.6^{\mathrm{a}} \pm 2.1$ & $42.3^{\mathrm{b}} \pm 1.8$ \\
SGR & $2.2^{\mathrm{a}} \pm 0.1$ & $2.2^{\mathrm{a}} \pm 0.2$ & $2.2^{\mathrm{a}} \pm 0.2$ & $1.8^{\mathrm{b}} \pm 0.1$ \\
PER & $2.1^{\mathrm{a}} \pm 0.1$ & $2.0^{\mathrm{a}} \pm 0.1$ & $1.9^{\mathrm{a}} \pm 0.2$ & $1.7^{\mathrm{a}} \pm 0.2$ \\
\hline
\end{tabular}

${ }^{a b c}$ Row means with common superscript do not differ $(\mathrm{P}>0.05)$

Diets $\mathrm{SBM}_{1}, \mathrm{SBM}_{2}, \mathrm{SBM}_{3}$ contain 100, 200, $300 \mathrm{~g}$ hazelnut meal $/ \mathrm{kg}$, respectively

In W - initial body weight; Fi W - final body weight; FI - feed intake; BWG - body weight gain; FCR - feed conversion ratio; SGR - specific growth rate, PEF - protein efficiency ratio 
Table 7 Whole body composition (\%) (wet weight basis) of mirror carp fed the test diets in Experiment II where soyabean meal (SBM) protein was partially replaced by protein in hazelnut meal $(n=6)$

\begin{tabular}{lrrrr}
\hline Constituents (\%) & \multicolumn{1}{c}{ Control } & \multicolumn{1}{c}{$\mathrm{SBM}_{1}$} & \multicolumn{1}{c}{$\mathrm{SBM}_{2}$} & \multicolumn{1}{c}{$\mathrm{SBM}_{3}$} \\
\hline Dry matter & $28.8^{\mathrm{a}} \pm 0.9$ & $29.9^{\mathrm{a}} \pm 0.7$ & $29.5^{\mathrm{a}} \pm 0.7$ & $29.0^{\mathrm{a}} \pm 0.8$ \\
Protein & $12.9^{\mathrm{a}} \pm 0.1$ & $13.0^{\mathrm{a}} \pm 0.2$ & $12.1^{\mathrm{a}} \pm 0.1$ & $12.3^{\mathrm{a}} \pm 0.2$ \\
Fat & $13.0^{\mathrm{a}} \pm 0.2$ & $12.5^{\mathrm{ab}} \pm 0.2$ & $11.6^{\mathrm{b}} \pm 0.3$ & $12.4^{\mathrm{ab}} \pm 0.4$ \\
Ash & $1.6^{\mathrm{a}} \pm 0.2$ & $1.7^{\mathrm{a}} \pm 0.1$ & $1.7^{\mathrm{ab}} \pm 0.1$ & $2.1^{\mathrm{b}} \pm 0.1$
\end{tabular}

${ }^{\text {abc }}$ Row means with common superscript do not differ $(\mathrm{P}>0.05)$

Diets $\mathrm{SBM}_{1}, \mathrm{SBM}_{2}, \mathrm{SBM}_{3}$ contain 100, 200, $300 \mathrm{~g}$ hazelnut meal $/ \mathrm{kg}$, respectively

\section{Discussion}

The present study demonstrated the potential of HM for inclusion in commercial carp diets. There is no information in the scientific literature concerning the use of HM in carp diets, particularly feeds produced under commercial conditions. There is a considerable benefit related to the replacement of part of the FM and SBM currently used in feeds. One of the most commonly encountered difficulties when alternative protein sources are used, is acceptability due to the palatability of the diets fed to fish (Rodrigez et al., 1996). In the current study, no palatability problem was encountered with any of the treatments during the experiments.

The present study indicated that HM can replace up to $35 \%$ of the protein in FM and $40 \%$ of the protein in SBM in fingerling carp diets without adverse effects on growth performance, feed utilization efficiencies and body composition. Several researches reported that FM in fish diets can be replaced by plant protein sources. Carter \& Hauler (2000) found that a pea protein concentrate could replace at least 33\% FM protein in the diets of Atlantic salmon. Extruded salmon feeds that contained up to $27 \%$ pea protein concentrate or $22 \%$ lupin protein concentrate had no significant effect on the growth performance of Atlantic salmon parr, compared to FM and solvent-extracted SBM (Watanabe \& Pongmaneerat, 1993). Several plant protein sources gave promising results when partially substituting FM (Hasan et al., 1997). At inclusion levels of between 25 and 50\%, linseed gave the best results followed by groundnut and sesame.

The source of dietary carbohydrate, inclusion level and balance between macronutrients affect glucose metabolism to a large degree in fish. In terms of feed utilization, protein sparing and growth stimulation, omnivorous species do show improved growth if fed a low-starch diet compared with a diet altogether devoid of starch (Hemre et al., 2002). However, these findings are different from that of Olvera et al. (1998) who observed reduced growth in tilapia fry fed diets containing 9 to 33\% Sesbania grandiflora meal. However, in this study very small-sized tilapia fry $(0.32 \mathrm{~g})$ were used. The smaller fish may have been more sensitive to the effect of anti-nutritional factors than bigger ones. Again, the effect of anti-nutritional factors may vary from species to species (Makkar \& Becker, 1999). In the present study all growth parameters of the fish on the $\mathrm{FM}_{3}$ and $\mathrm{SBM}_{3}$ diets were lower $(\mathrm{P}<0.05)$ than those on the other diets. The results suggest the $45 \%$ replacement of FM protein and a $60 \%$ replacement of SBM protein with HM may not provide optimal growth performance in carp, while partial replacement (up to 35\% FM and 40\% SBM) may be advantageous and would lead to a reduction in feed costs. Weight gain is affected by the quantity and quality of the protein in the diet. Since the diets were calculated to be isonitrogenous and isoenergetic, the poorer performances of carp receiving the diets where HM protein replaced $45 \%$ of the protein from FM and $60 \%$ of that from SBM might be due to an inferior quality of the HM protein. Furthermore, the growth depression at these high levels of HM could be attributed also to a high fibre content of the diets, which would reduce the digestibility of the diet. Fibre causes dilution of nutrients and reduces digestibility because the diet becomes inconsistent (Adebayo et al., 2004). In addition, this could be the result of several factors, including reduced nutrient and energy digestibility and efficiency of energy utilization. The PER also decreased and FCR increased with increasing inclusion level of HM. This may reflect a deficiency of one or more amino acids in these diets. All these values in diets $\mathrm{FM}_{3}$ and $\mathrm{SBM}_{3}$ were significantly lower and decreased with the higher inclusion of HM in the diets. 
Diets containing higher levels of HM produced the lowest whole body fat values (Table 5). This result is in agreement with findings of Yurkowski et al. (1978) who observed similar reductions in whole body fat in rainbow trout fed diets containing rapeseed meal that contains tannin and glucosinolates. The whole body protein content of mirror carp fingerlings fed different diets did not show large variations. However, the whole body lipid contents showed large variations. This result is in agreement with findings of Atack et al. (1979) and Hasan \& Macintosch (1993) who suggested that the lipid content of fish always tend to show greater fluctuations than other carcass components. This observation is also in agreement with the study by Hossain \& Jauncey (1989) who observed a reduction in carcass lipids in common carp fed diets containing mustard oilcake, which contains tannin and glucosinolates. Applier \& Jauncey (1983) also observed marked decreases in carcass lipid contents on Oreochromis niloticus fed diets containing filamentous algae as the partial or sole source of dietary protein.

One of the limitations of the current study is the small number of fish used. Before large-scale implementation, further investigations with a larger number of fish are required to validate the obtained results.

\section{Conclusion}

It was concluded that protein in HM can effectively replace up to $35 \%$ of protein in FM and $40 \%$ of that in soyabean meal in mirror carp fingerling diets without any adverse effects on growth, survival, FCR, PER, BWG, FI and body composition. These results therefore demonstrate that HM can be included in diets formulated for commercial production of mirror carp fingerling. However, it should be emphasized that in none of diets FM was replaced completely. Even in the SBM trial FM supplied a large proportion of the amino acids in the diets.

\section{Acknowledgment}

The authors would like to thank Unal Kilic from The University of OMU, Samsun, Turkey for providing the hazelnut meal used in this study.

\section{References}

Adebayo, O.T., Fagbenro, O.A. \& Jegede, T., 2004. Evaluation of Cassia fistula meal as a replacement for soybean meal in practical diets of Oreochromis niloticus fingerlings. Aquaculture Nutr. 10, 99-104.

AOAC, 1990. Official Methods of Analysis (15th ed.) Association of Official Analytical Chemists, Washington, D.C., USA. pp. 69-88.

Applier, H.N. \& Jauncey, K., 1983. The utilization of filamentous green algae (Cladophora glomerata) as protein source in pelleted feeds for Sarotherodon (tilapia) niloticus fingerlings. Aquaculture 30, 21-30.

Atack, T.H., Jauncey, K. \& Matty, A., 1979. The utilization of some single cell protein by fingerling mirror carp (Cyprinus carpio). Aquaculture 18, 337-348.

Bilgin, O. \& Turker, A., 2006. The possibility of usage hazelnut meal as a substitute for soybean meal in rainbow trout diets Oncorhynchus mykiss. Meeting Abstract. Florence, Italy, May 9-12, AQUA 2006.

Buyukcapar, H.M. \& Kamalak, A., 2006. Raw and heat treated Culban (Vicia peregrine) seeds as dietary protein source for mirror carp (Carpinus carpio) fingerlings. S. Afr. J. Anim. Sci. 36, 235-242.

Carter, C.G. \& Hauler, R.C., 2000. Fish meal replacement by plant meals in extruded feeds for Atlantic salmon, Salmo salar L. Aquaculture 185, 299-311.

Davies, S.J., McDonnell, S. \& Bateson, R.I., 1990. Potential of rapeseed meal as an alternative protein sources in complete diets for tilapia (Oreochromis mossambicus). Aquaculture 87, 145-154.

Fabgenro, O., 1999. Comparative evaluation of heat processed Winged bean (Psophocarpus tetragonolopus) meals as partial replacement for fish meal in diets for the African catfish (Clarias garipenius). Aquaculture 170, 297-305.

Gouveia, A. \& Davies, S.J., 1998. Preliminary nutritional evaluation of pea seed meal (Prism sativum) for juvenile European sea bass (Dicentrarchus labrax). Aquaculture 166, 311-320.

Hasan, M.R. \& Macintosh, D.J., 1993. Effect of environmental temperature and feeding rate on the growth, food utilization and body composition of common carp (Cyprinus carpio) fry. In: Fish Nutrition in Practice. Eds. Kaushik, S.J. \& Luquet, M.R., INRA, Paris. pp. 767-778. 
Hasan, M.R., Macintosh, D.J. \& Jauncey, K., 1997. Evaluation of some plant ingredients as dietary protein sources for common carp (Cyprinus carpio L.) fry. Aquaculture 151, 55-70.

Hemre, G.I., Mommsen, T.P. \& Krogdahl, A., 2002. Carbohydrates in fish nutrition; effects on growth, glucose metabolism and hepatic enzymes. Aquaculture Nutr. 8, 175-194.

Hossain, M.A. \& Jauncey, K., 1989. Nutritional evaluation of some Bangladeshi oil seed meals as partial substitutes for fish meal in the diets of common carp Cyprinus carpio L. Aquacul. Fish. Manage. 20, 255-268.

Hossain, M.A., Focken, U. \& Becker, K., 2001. Evaluation of an unconventional legume seed, Sesbenia aculeata, as a dietary protein source for common carp, Cyprinus carpio L. Aquaculture 198,129-140

Kaushik, S.J., Cravedi, J.P., Lalles, J.P., Sumpter, J., Fauconneau, B. \& Laroche, M., 1995. Partial or total replacement of fish meal by soybean protein on growth, protein utilization, potential estrogenic or antigenic effects, choloscrolema and flesh quality in Rainbow trout, Oncorhynchus mykiss. Aquaculture 133, 257-274.

Lim, C. \& Akiyama, D., 1992. Full fat utilization of soybean meal by fish. Asian Fish. Sci. 5, 181-197.

Makkar, H.P.S. \& Becker, K., 1999. Nutritional studies on rats and fish (carp, Cyprinus carpio) fed diets containing unheated and heated Jatropha curcas meal of a non-toxic provenance. Plant Foods Human Nutr. 53, 183-192.

Naylor, R.L., Goldburg, J., Primavera, J.H., Kayutsky, N., Beveridge, M.C.M., Clay, J., Folke, C., Lubchenco, J., Money, H. \& Troell, M., 2000. Effect of aquaculture on world fish supplies. Nature 405, 1017-1024.

NRC, 1993. Nutrient Requirements of Fish. National Academy Press, New York, USA.

Oliva-Teles, A., Gouveia, A.J., Gomes, E. \& Rema, P., 1994. The effect of different processing treatments on soybean meal utilization by rainbow trout, Oncorhynchus mykiss. Aquaculture 124, 343-349.

Olvera, N.M.A., Martinez, P., Carlos, A., Galvan, C.R. \& Chavez, S.C., 1998. The use of seed of the legumes plant Sesbenia grandiflora as a partial replacement for fish meal in diets for tilapia (Oreochromis mossambicus). Aquaculture 158, 107-116.

Refstie, S., Storebakken, T. \& Roem, A.J., 1998. Feed and consumption and conversion in Atlantic salmon (Salmo salar) fed diets with fish meal, extracted soybean meal or soybean meal with reduced content of oligosaccharides, trypsin inhibitors, lectins and soya antigens. Aquaculture 162, 302-312.

Rodriguez, S.M., Overa, N.M.A. \& Carmona, O.C., 1996. Nutritional value of animal by-product meal in practical diets for Nile tilapia, Oreochromis niloticus (L) fry. Aquaculture Res. 27, 67-73.

Rumsey, G.L., Hughes, S.G. \& Winfree, R.A., 1993. Chemical and nutritional evaluation of soybean protein preparations as primary nitrogen sources for rainbow trout (Oncorhynchus mykiss). Anim. Feed Sci. Technol. 40, 135-151.

Siddhuraju, P. \& Becker, K., 2001. Preliminary nutritional evaluation of Macuna seed meal (Macuna pruriens utilis) in common carp (Cyprinus carpio L.); an assessment by growth performance and feed utilization. Aquaculture 26, 223-236.

Siddhuraju, P. \& Becker, K., 2002. Effect of phenolic nonprotein amino acid L-dopa (L-3, 4-dihydroxphenyalanine) on growth performance, metabolic rates and feed nutrient utilization of common carp (Cyprinus carpio L.). Aquaculture Nutr. 8, 69-77.

SIS, 2004. The Summary of Agricultural Statistics. State Institute of Statistics, Prime Ministry of the Republic of Turkey. Publication Number: 2921. Printing Division of State Institute of Statistics. Ankara, Turkey.

Statistica, 1993. Statistica for windows release 4.3, StatSoft, Inc. Tulsa, O.K., USA.

Tacon, A.G.J. \& Jackson, A.J., 1985. Utilization of conventional and unconventional protein sources in practical fish feeds. In: Nutrition and Feeding in Fish. Eds. Cowey, C.B., Mackie, A.M. \& Bell, J.G., Academic Press, London. pp. 119-145.

Watanabe, T. \& Pongmaneerat, J., 1993. Potential of soybean meal as protein source in extruded pellets for rainbow trout diets. Nippon Suisan Gakkaishi 59, 1415-1423.

Webster, C.D., Yancey, D.H. \& Tidwell, J.H., 1992. Effect of partially or totally replacing fish meal with soybean meal on growth of blue catfish (Ictalurus furcatus). Aquaculture 103, 141-152. 
Yalcin, S., Oguz, F. \& Yalcın, S., 2005. Effect of dietary hazelnut meal supplementation on the meat composition of quails. Turk. J. Vet. Anim. Sci. 29, 1285-1290.

Yurkowski, M., Baily, J.K., Evans, R.E., Tabachek, J.A.L., Ayles, G.B. \& Eales, J.G., 1978. Acceptability of rape seed proteins in diets of rainbow trout (Salmo gairdnerii). J. Fish Res. Board, Canada. 35, 951-962. 